\title{
MODELLING OF HYDROPOWER RESERVOIR VARIABLES FOR ENERGY GENERATION: NEURAL NETWORK APPROACH
}

*ABDULKADIR, T. S., ${ }^{1}$ SALAMI, A. W., ${ }^{1}$ ANWAR, A. R. ${ }^{1}$ and KAREEM, A. G. ${ }^{2}$

http://dx.doi.org/10.4314/ejesm.v6i3.12

\section{Received 9th February 2013; accepted 22nd April 2013}

\begin{abstract}
Efficient management of hydropower reservoir can only be realized when there is sufficient understanding of interactions existing between reservoir variables and energy generation. Reservoir inflow, storage, reservoir elevation, turbine release, net generating head, plant use coefficient, tail race level and evaporation losses are the major hydropower reservoir variables affecting the energy generation. Thus, this paper presents the modelling of reservoir variables of two hydropower dams along the River Niger (Kainji and Jebba dams) in Nigeria for energy generation using multilayer perceptron neural network. Total monthly historical data of Kainji and Jebba hydropower reservoirs' variables and energy generated were collected from Power Holding Company of Nigeria respectively for a period of (1970-2011) and (1984-2011) for the network training. These data were divided into training, testing and holdout data set. The neural network summary yielded a good forecast for Kainji and Jebba hydropower reservoirs with correlation coefficients of 0.89 and 0.77 respectively. These values of the correlation coefficient showed that the networks are reliable for modeling energy generation as a function of reservoir variables for future energy prediction.
\end{abstract}

Key words: Hydropower, reservoir variables, neural network, energy generation, coefficient of correlation

\section{Introduction}

Energy is one of the most basic needs of all people in the world. Among other sources of energy; natural gas, bio-fuel, wind, solar, etc, hydropower is found to be of highest grade of energy (Sambo, 2006). Hydroelectricity comes from the conversion of potential energy of water through turbines and electric generator system. Aliyu and Elegba (1990) indicated that Nigeria is endowed with several potential renewable sources of energy and identified a total of seventy (70) micro dams, one hundred and twenty six (126) mini dams and eighty six (86) small hydropower sites along numerous river systems. Despite these enormous resources, electricity is grossly inadequate. In Nigeria, electricity generation has not been fully developed as reported by Ifabiyi (2011a) that the total energy consumption comprises of $5.22 \%$ of natural gas, $3.05 \%$ of hydroelectricity and $50.45 \%$ natural gas and $50.45 \%$ of fuel work. According to Ajao et al. (2009), hydropower potential of Nigeria is very high and currently accounts for about $29 \%$ of the total electrical power supply.

Hydropower (HP) is one of the few sources of energy that has assumed great significance since the beginning of the twentieth century. One of the major reasons that make HP attractive is that water, like wind and sun, is a renewable resource and is sustainable through the hydrologic cycle (Sule et al., 2009). It was also observed (Aribisala and Sule, 1998) that HP systems are easy to run and generally have low maintenance cost compared to other sources of energy. Although HP project require high initial investment cost. According to Sule et al. (2009), many nations today derive sizeable portions of their energy needs from it. Salami and Sule (2012) reported that Diaz and Fontane in 1989 indicated that hydroelectric plants have a major advantage over other energy sources in supplying peaking power in that generation rates can be varied rapidly and efficiently. Also, HP has nearly zero pollution emissions, and ability to quickly respond to peak loads makes it a valuable source of renewable energy. In the United States, HP facilities are diverse; facilities range from multipurpose dams with large reservoirs to small run-of-river dams with little or no active water storage. According to Kaveh and Jay (2009), high-elevation hydropower plants are generally located below small (withinyear storage) reservoirs with high turbine heads compared with much larger multipurpose reservoirs with lower head downstream (lower elevations).

\footnotetext{
${ }^{1}$ Department of Civil Engineering, University of Ilorin, P.M.B.

${ }^{2}$ National Agency for Science and Engineering Infrastructure,

Garki, Abuja, Nigeria

*Corresponding author: abdulkadirts4u@gmail.com
} 
Modelling of Hydropower Reservoir Variables for Energy Generation...................Abdulkadir et al.

Isa et al. (2007) studied inter-basin water transfer solution to the Kainji reservoir, from the tail-water releases at the Jebba reservoir and the lateral flow from other river basins collecting at Baro and Lokoja. The study revealed that out of about $178.36 \mathrm{~km}^{3}$ of water lost to the ocean through the Niger delta only $31.23 \mathrm{~km}^{3}$ of that is obtained from the western borders of Nigeria where the two hydro-power stations are located. However, there are low inflow situations resulting from drought and increased pressure on the available water resources of the Niger basin by countries upstream Kainji reservoir. These activities are currently hindering the optimum power generation in Kainji and Jebba HP located on the Niger River. Depending on hydrological conditions, hydropower provides 5-10\% of electricity used in United State (National Energy Education Development, 2007). Thus, water resources management is very crucial to hydropower generation. Efficient water management can only be realized when there is sufficient understanding of the complex interactions between reservoir elements and electricity generation (Sharma, 1985). Salami and Sule (2012) developed optimal water management model for hydropower system on river Niger in Nigeria by considering Kainji and Jebba as a system. The study revealed that about $41 \%$ additional energy can be generated. Fabiyi (2011b) examined the interaction that exist within the following reservoir elements: minimum inflow, storage balance, lake evaporation, average outflow, peak inflow, peak outflow, reservoir level, average inflow, minimum outflow and discharge. It was identified that few elements are most relevant to electricity generation and their level of relevance varies from months to month. However, during low flows the reservoir elements have negligible roles in power generation. Also, in the flood seasons, the output terms are dominant in dam operations in order to prevent dam failure and wastage of energy. The study also revealed that a causal relationship exists between hydroelectricity and reservoir elements.

In recent years, data driven modelling is emerging. These data serves as a source of information for the development of model and to build a rule to simulate the operation of hydrological and hydraulic systems. Thus, artificial intelligence tools such as genetic algorithms, neural network (NN) and fuzzy logic are increasingly used as soft computing techniques to solve modelling issues (Abdulkadir et al., 2012a). A neutral network (NN) in the context of statistical analysis is an alternative to or in addition to multiple regressions which is an information processing paradigm that is inspired by the way biological nervous systems, such as the brain, process information (Andy et al., 2004; Hung et al., 2008; and Abdulkadir et al., 2012b). The main advantage of NN lies in handling noisy data, addressing non-linear and dynamic systems (Swingler, 1996). Of recent, there is a significant advancement in the application of $\mathrm{NN}$ in modelling, especially in the field of hydrology and hydraulic engineering. In this study, the goal is to develop an NN model for the modeling of interaction of hydropower generated (energy generation) in relation to hydropower reservoir elements such as reservoir inflow, storage, reservoir elevation, evaporation loss, turbine release, net generating head, plant use coefficient and tail race level.

\section{Methodology \\ Study Area}

The Niger River is the third longest river in Africa after the Nile and Congo/Zaire Rivers. It has a total length of about $4200 \mathrm{~km}$ with a theoretical area of about 2 million sq $\mathrm{km}$. This area has reduced to an active catchment area of just about 1.5 million sq $\mathrm{km}$ thus excluding Algeria which is among the 10 countries covered by the Niger River basin. Other countries are Benin, Burkina Faso, Cameroon, Chad, guinea, Ivory Coast, Mali, Niger, and Nigeria.The study area, Kainji and Jebba hydropower reservoirs, are located in the lower Niger basin majorly for hydroelectric power generation. The flow of river Niger downstream of Jebba dam is governed by the operations of the Kanji and Jebba hydroelectric schemes and runoff from the catchments (Sule et al, 2009). Kainji hydropower reservoir was the first hydropower generation station in Nigeria with an installed capacity of 760MW and provisions for expansion to $1156 \mathrm{MW}$ while the second hydropower station on the same river is at Jebba with an installed capacity of 540 MW. Kainji construction was between 1964 and 1968 while Jebba HP was constructed between 1979 and 1983 and located at about $100 \mathrm{Km}$ downstreamof Kainji on latitude $9^{0} 06^{1} \mathrm{~N}$ and longitude $4^{0} 50^{1} \mathrm{E}$. It extends for about $10 \mathrm{~km}$ (about 6mi), including its saddle dam, which closes off a tributary valley. Most of the structure is made from earth, but the 
center section, housing the hydroelectric turbines, was built from concrete. Kainji Lake is about $135 \mathrm{~km}$ (about $84 \mathrm{mi}$ ) long and 30km (20 mi) wide across at its widest point (Roder, 2008). Other features of the two HP reservoirs are as shown in Table 1 and location map is shown in Figure 1.

Table 1 Features of Kainji and Jebba Hydropower Reservoirs

\begin{tabular}{lll}
\hline Reservoir Features & Kainji & Jebba \\
\hline First year of operation & 1968 & 1984 \\
Installed capacity (MW) & 760 & 540 \\
Design power plant factor & 0.86 & 0.70 \\
Number of generators & 8 & 6 \\
Reservoir flood storage capacity $\left(\mathrm{Mm}^{3}\right)$ & 15,000 & 4,000 \\
Reservoir flood level (m) & 143.50 & 103.55 \\
Maximum operating reservoir elevation (m.a.s.l) & 141.83 & 103.00 \\
Minimum operating reservoir elevation (m.a.s.l) & 132.00 & 99.00 \\
Maximum storage (active storage capacity), $\left(\mathrm{Mm}^{3}\right)$ & 12,000 & 3,880 \\
Minimum storage (Dead storage capacity), $\left(\mathrm{Mm}^{3}\right)$ & 3,000 & 2,880 \\
\hline
\end{tabular}

Source: Power Holding Company of Nigeria (PHCN), 2012

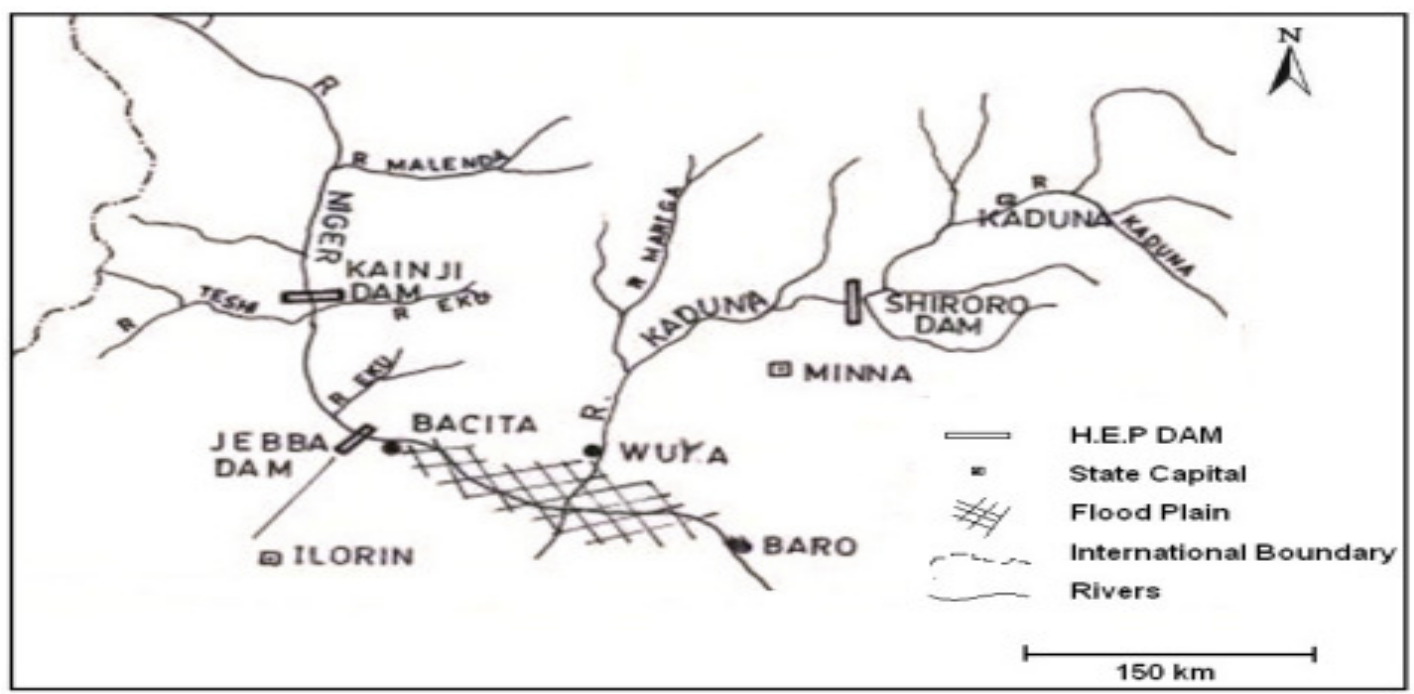

Figure 1 Location Map of the Kainji and Jebba Hydropower Reservoirs on Niger River

Statistical Analysis of HP Reservoir variables of Kainji and Jebba Reservoirs

Total monthly historical data of HP reservoir variables for Kainji and Jebba stations were analyzed. The data include reservoir inflow $\left(\mathrm{Mm}^{3}\right)$, storage $\left(\mathrm{Mm}^{3}\right)$, reservoir elevation $(\mathrm{m})$, turbine release $\left(\mathrm{Mm}^{3}\right)$, net generating head $(\mathrm{m})$, plant use coefficient, tail race level (m), evaporation losses $\left(\mathrm{Mm}^{3}\right)$ and energy generation (MWh). These data were collected from Power Holding Company of Nigeria (PHCN) for a period forty two years (1970-2011) for Kainji and twenty eight years (1984-2011) for Jebba station. The summary of the statistical analysis is presented in Tables $2 \mathrm{a}$ and $2 \mathrm{~b}$ for Kainji and Jebba HP reservoirs respectively. 
Table 2a Summary of Statistical Analysis of the Kainji HP Data (1970 - 2011)

\begin{tabular}{lrrrrrrr}
\hline \multicolumn{1}{c}{ Reservoir Elements } & Mean & Median & S.D & C.V & Minimum & Maximum & Skew \\
\hline Reservoir Inflow $\left(\mathrm{Mm}^{3}\right)$ & 2504.35 & 2408.77 & 632.93 & 0.25 & 1396.93 & 3653.04 & 0.44 \\
Reservoir Storage $\left(\mathrm{Mm}^{3}\right)$ & 8058.58 & 8088.18 & 722.04 & 0.09 & 6654.53 & 9258.92 & -0.17 \\
Reservoir Elevation $(\mathrm{m})$ & 138.17 & 138.12 & 0.67 & 0.00 & 136.86 & 139.34 & 0.00 \\
Turbine Release $\left(\mathrm{Mm}^{3}\right)$ & 1881.96 & 1880.54 & 419.47 & 0.22 & 1131.05 & 2806.00 & 0.18 \\
Net Generating Head (m) & 38.57 & 38.48 & 0.59 & 0.02 & 37.63 & 39.90 & 0.41 \\
Energy Generation $(\mathrm{MWh})$ & 178570.26 & 158016.25 & 73090.93 & 0.41 & 81553.53 & 378612.85 & 1.13 \\
Plant Use Coefficient & 0.39 & 0.35 & 0.15 & 0.39 & 0.17 & 0.80 & 1.06 \\
Tail Race Level $(\mathrm{m})$ & 100.97 & 100.37 & 1.92 & 0.02 & 98.02 & 103.83 & 0.26 \\
Evaporation Loss $\left(\mathrm{Mm}^{3}\right)$ & 145.20 & 146.00 & 5.30 & 0.04 & 138.52 & 152.10 & -0.09 \\
\hline
\end{tabular}

Note: S.D = Standard deviation, $C . V=$ Coefficient of variation

Table 2b Summary of Statistical Analysis of the Jebba HP Data (1984 - 2011)

\begin{tabular}{lrrrrrrr}
\hline Reservoir Elements & Mean & Median & S.D & C.V & Minimum & Maximum & Skew \\
\hline Reservoir Inflow $\left(\mathrm{Mm}^{3}\right)$ & 2647.90 & 2474.85 & 729.23 & 0.28 & 1588.86 & 4154.26 & 0.51 \\
Reservoir Storage $\left(\mathrm{Mm}^{3}\right)$ & 3595.74 & 3594.00 & 79.81 & 0.02 & 3423.55 & 3751.58 & 0.13 \\
Reservoir Elevation $(\mathrm{m})$ & 102.01 & 101.99 & 0.34 & 0.00 & 101.22 & 102.60 & -0.17 \\
Turbine Release $\left(\mathrm{Mm}^{3}\right)$ & 2182.05 & 2186.21 & 297.70 & 0.14 & 1566.66 & 2572.62 & -0.37 \\
Net Generating Head $(\mathrm{m})$ & 28.15 & 28.22 & 0.54 & 0.02 & 26.61 & 29.07 & -1.05 \\
Energy Generation $(\mathrm{MWh})$ & 175134.17 & 163525.08 & 54346.26 & 0.31 & 103542.36 & 282039.95 & 0.77 \\
Plant Use Coefficient & 0.47 & 0.45 & 0.15 & 0.33 & 0.26 & 0.72 & 0.20 \\
Tail Race Level $(\mathrm{m})$ & 73.69 & 73.61 & 0.40 & 0.01 & 73.09 & 74.54 & 0.64 \\
Evaporation Loss $\left(\mathrm{Mm}^{3}\right)$ & 49.28 & 49.30 & 1.90 & 0.04 & 45.57 & 51.27 & -0.77 \\
\hline
\end{tabular}

Note: S.D = Standard deviation, $C . V=$ Coefficient of variation

Application of NN Model to Kainji and Jebba HP Reservoir Variables

The data sets were partitioned into three; training, testing and holdout samples for each of the stations. The training data records were used to train the neural network in order to obtain a model. The testing sample is an independent set of data records used to track errors during training in order to prevent overtraining. The holdout sample is another independent set of data records used to assess the final neural network; the error for the holdout sample gives an estimate of the predictive ability of the model. In this study, multilayer perceptron (MLP) was adopted with sigmold activation function both at hidden and output layers. A normalized method of rescaling was used for scaling the HP reservoir variables. The neural network was trained with 504 data for Kainji station and 336 data for Jebba station. The data for each of the stations include reservoir inflow $\left(\mathrm{Mm}^{3}\right)$, storage $\left(\mathrm{Mm}^{3}\right)$, reservoir elevation $(\mathrm{m})$, turbine release $\left(\mathrm{Mm}^{3}\right)$, net generating head (m),plant use coefficient, tail race level (m) and evaporation losses $\left(\mathrm{Mm}^{3}\right)$ as input layers and energy generation (MWh) as output layer. In the training process, the weights of input layer and hidden layer nodes are adjusted by checking the training and testing stage performances of neural networks. The coefficient of correlation and the mean square error are the performance criteria for the testing stage.

\section{Results and Discussion}

The historical total monthly data for each of Kainji and Jebba HP reservoirs' variables were statistically analyzed. Statistical parameters such as mean, median, standard deviation, coefficient of variation, minimum, maximum and skewness were computed for each of the variables as shown in Tables 2a and 2b. Application of NN model to Kainji and Jebba HP reservoirs data, reservoir inflow, storage, reservoir elevation, turbine release, net generating head, plant use coefficient, tail race level and evaporation losses were used as input layers and energy generation as output layer for the training of the network. This training involves estimation of main controlling parameters called network weights. A supervised training algorithm otherwise known as feed forward backpropagation or MLP algorithm was adopted. Neural network model as applied to Kainji and Jebba HP reservoir variables yielded a network structure containing 8: 7: 1 of input, hidden and output layers network structure. The generated 
model structure is as shown in Figure 2. After training, the neural network models and test performances were checked. The performances of neural network models for prediction of energy generation were demonstrated in Figures 3 and 4 in the form of scatter plots. The correlation coefficients of 0.89 and 0.77 were obtained for Kainji and Jebba HP reservoirs respectively. This shows that there is linear relationship between the network outputs (estimates) and the corresponding targets (observed data) for the test data set.

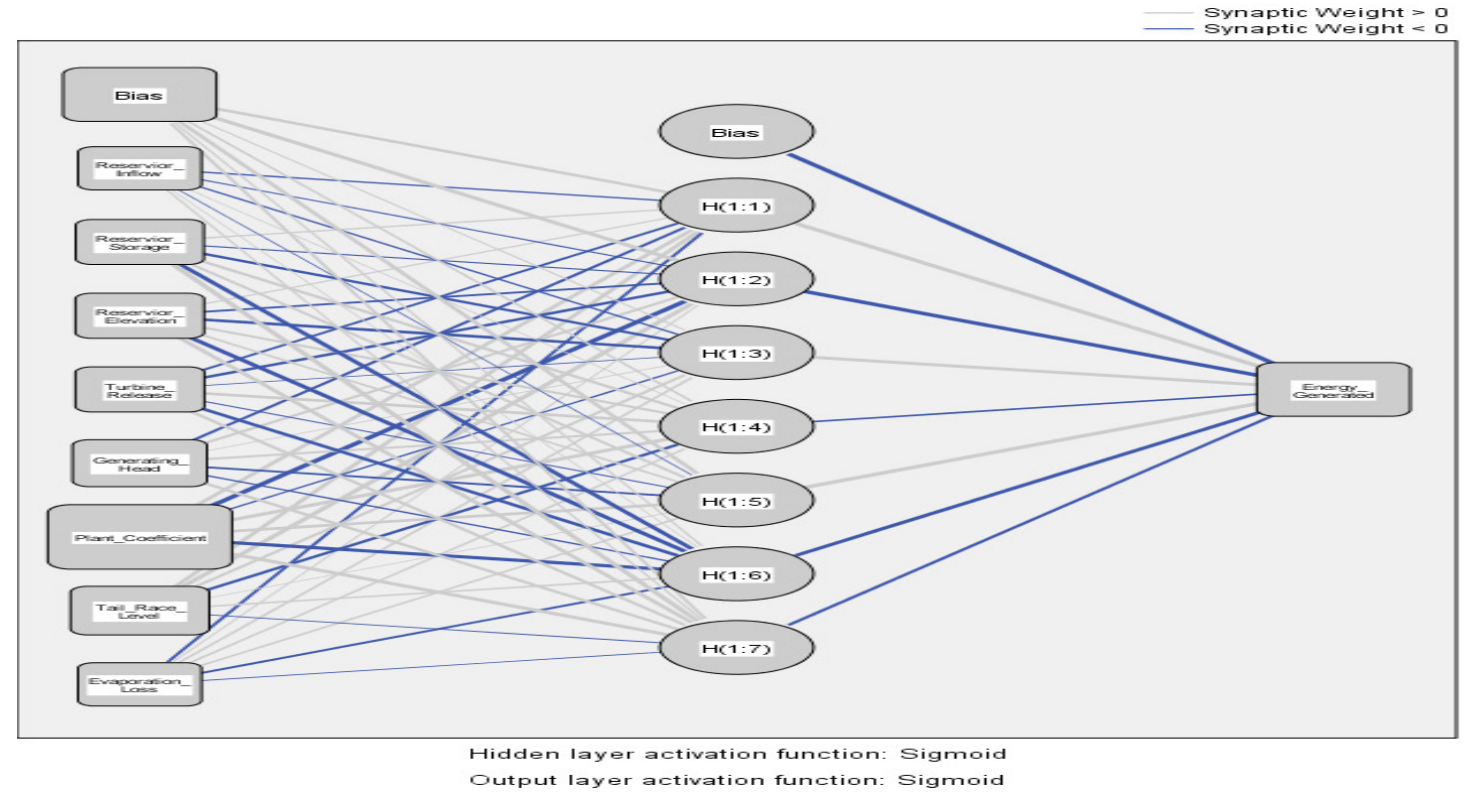

Figure 2 Generated Network Structure

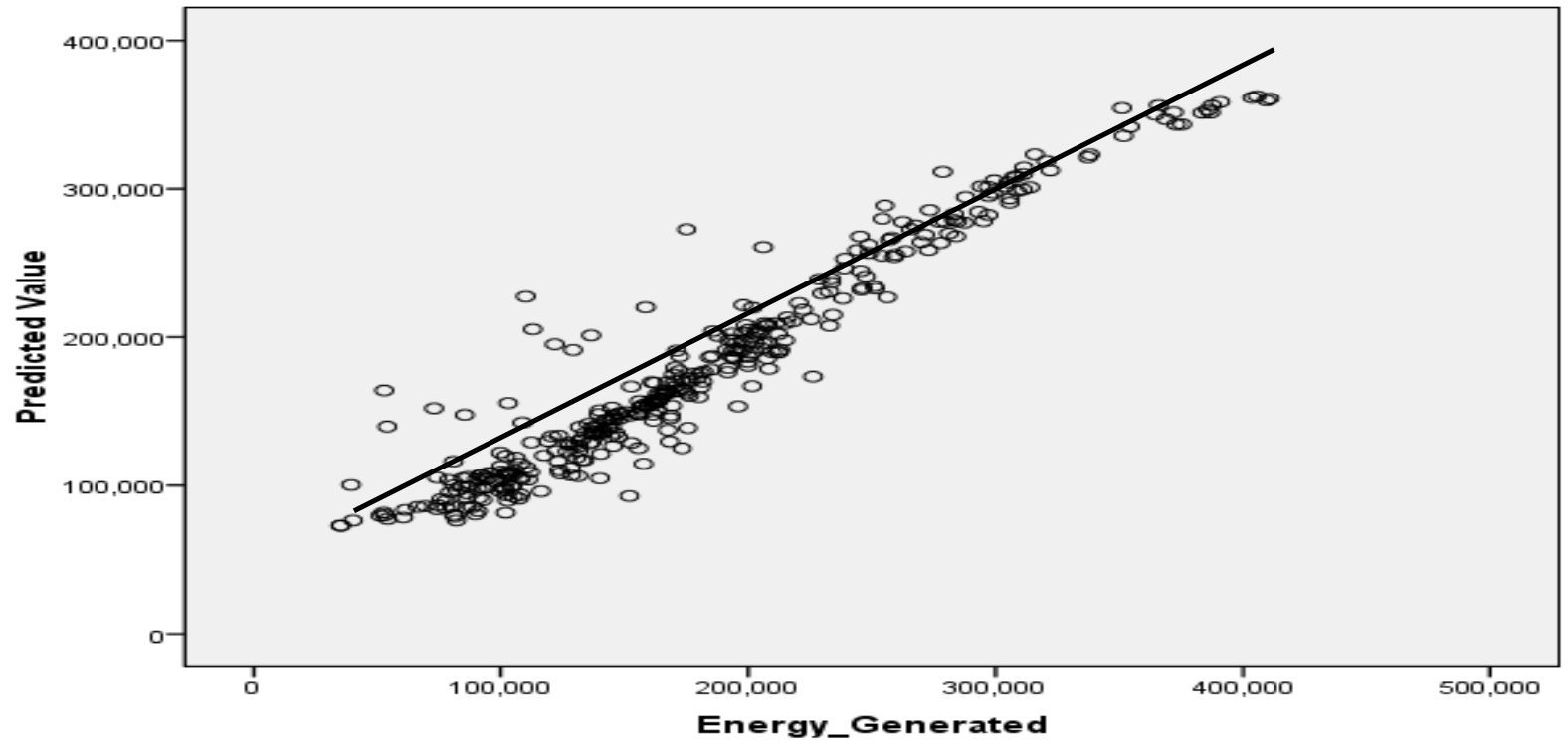

Figure 3 Scatter Plot of Predicted and Observed Energy Generated for Kainji HP 


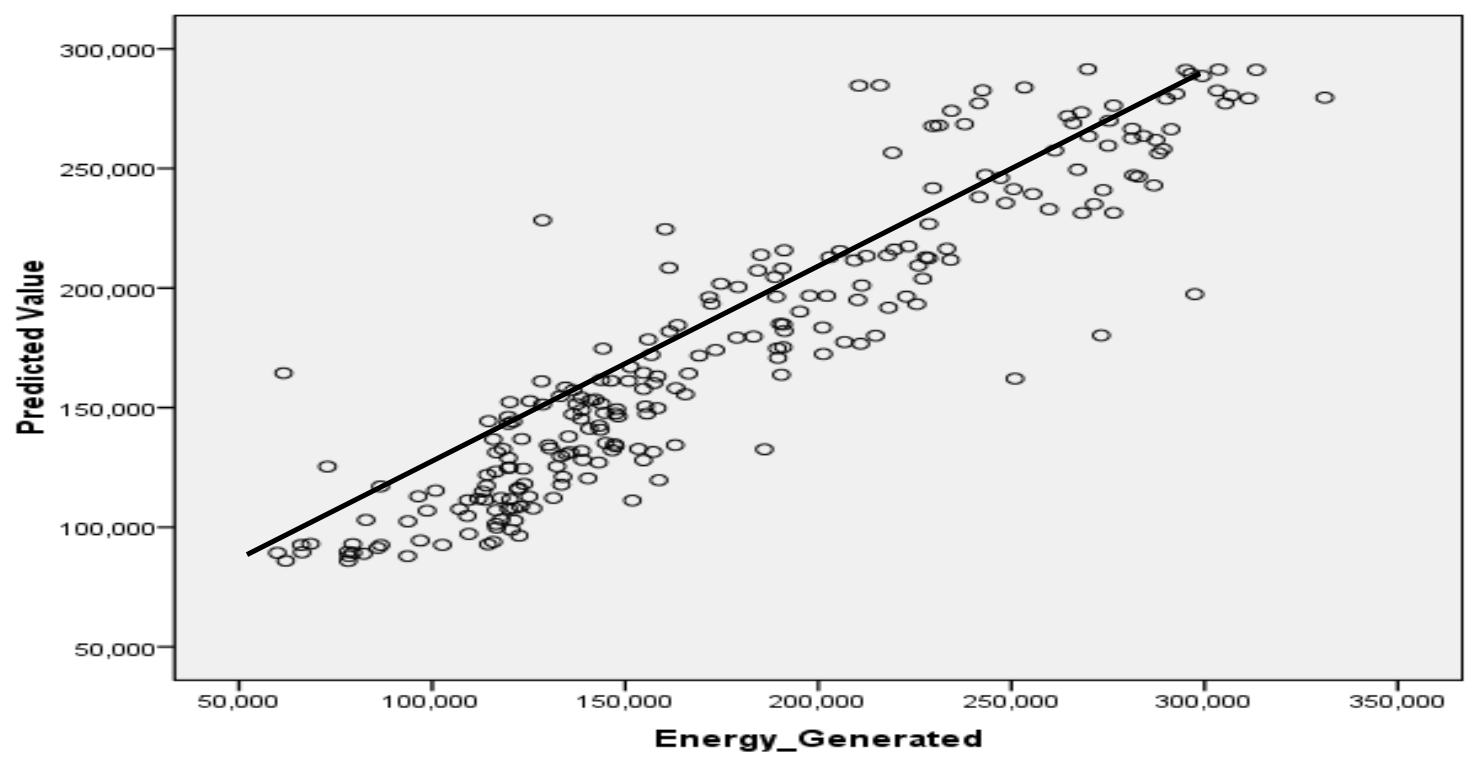

Figure 4 Scatter Plot of Predicted and Observed Energy Generated for Jebba HP

\section{Conclusion}

Energy generation from HP reservoir rely majorly on the adequate planning and operation of the reservoir which can be achieved through modeling of its variables in relation to energy generation. Kainji and Jebba hydropower reservoir variables were modeled for energy generation using neural network multilayer perceptron with sigmoid function as activator. Neural network model yielded a good forecast for Kainji and Jebba hydropower reservoirs with correlation coefficients of 0.89 and 0.77 respectively. These values showed strong linear relationship between the observed and predicted energy generation and this is an indication that the NN model is reliable for modeling of HP reservoirs for energy generation.

\section{Acknowledgement}

The authors acknowledge the management of Kainji and Jebba hydropower stations for providing the data and other information used in carrying out this study. The author would also like to thank the Department of Civil Engineering, University of Ilorin for providing technical support.

\section{References}

Abdulkadir, T. S., Salami, A. W. and Kareem, A. G. (2012a), Artificial Neural Network Modeling of Rainfall in Ilorin, Kwara State, Nigeria, USEP, Journal of Research Information in Civil Engineering, Vol. 9 No 1, pp. 108-120.
Abdulkadir, T. S., Sule, B. F. and Salami, A. W. (2012b), Application of Artificial Neural Network Model to the Management of Hydropower Reservoirs along River Niger, Nigeria. Annals of Faculty Engineering, Hunedoara-International Journal of Engineering, Tome X -FASCICULE 1(ISSN 1584-2673), pp. 419-424. Available online http://annals.fih.upt.ro/pdf-full/2012/ANNALS201

Ajao, K. R., Ajimotokan, H. A., Popoola, O. T. and Akande, H. F. (2009), Electric Energy Supply In Nigeria, Decentralized Energy Approach, New York Science Journal, http://www.sciencepub.net/newyork, ISSN 15540200, 2(5), pp. 84-92.

Aliyu, U. O. and Elegba, S. B. (1990), Prospects for Small Hydropower Development for Rural Applications in Nigeria, Nigerian Journal of Renewable Energy 1: pp. 74-86.

Andy P. D., Peter, L. M., Goethals, W. G. and Niels, D. P. (2004), Optimization of Artificial Neural Network Model Design for Prediction of Macro-invertebrates in the Zwalm River Basin, Ecological Modeling (174), pp. 161-173.

Aribisala, J. O. and Sule, B. F. (1998), Seasonal Operation of a Reservoir Hydropower System, Technical Transactions Nigerian Society of Engineers, NSE, 33 (2): pp. 1-14.

Hung, N. Q., Babel, M. S., Weesakul, S. and Tripathi, N. K. (2008), An Artificial Neural Network Model for Rainfall Forecasting in Bangkok, Thailand, Hydrol. Earth Syst. Sci. Discuss., 5, pp. 183-218. 
Ifabiyi, I. P. (2011a), Contributions of Reservoir Elements to Monthly Electricity Generation in the Jebba Hydropower Reservoir, Nigeria, Ozean Journal of Applied Sciences 4(3), pp. 251-264 Ifabiyi, I. P. (2011b), Relationship Between Power Generation and Reservoir Elements in the Jebba Hydroelectric Reservoir, Nigeria, Global Journal of Science Frontier Research, Volume 11 Issue 8 Version 1.0, USA, ISSN: 2249-4626, pp. 1-11

Isa U. E, Alayande A. W. and Bamgboye, O. A. (2007), Tail Water Recycling for Higher Efficiency in Hydropower (Case Study of KainjiJebba Hydropower Dams in Nigeria), International Conference on Small Hydropower - Hydro Sri Lanka, 22-24, October.

Kaveh, M. and Jay, R. L. (2009), Modeling California's High-Elevation Hydropower Systems in Energy Units, Water Resources Research, Vol. 45, W09413, doi:10.1029/2008WR007206

National Energy Education Development Project (2007), Hydropower, in Secondary Info Book, pp. 24 - 27, Need Proj., Manassas, Va.

Roder, W. (2008), Kainji Dam, Microsoft Encarta 2009 [DVD], Redmond, WA: Microsoft Corporation.
Salami, A. W. and Sule, B. F. (2012), Optimal Water Management Modelling for Hydropower System on River Niger in Nigeria, International Journal of Engineering, FASCICULE 1 (ISSN 1584-2665), Annals of Faculty of Engineering Hunedoara, Tome X, pp. 185-192.

Sambo, A.S. (2006), Renewable Energy Electricity in Nigeria: The Way Forward, Paper Presented at the Renewable Electricity Policy Conference Held at Shehu Musa Yar'adua Centre, Abuja, Nigeria.

Sharma, V. K. (1985), Water Resources Planning and Management, Himalaya Publishing House.

Sule, B. F., Salami, A. W. and Okeola, O. G. (2009), Operational Impact of Hydropower Generation and Highlights on Preventive Measures in Lowland Area of River Niger, Nigeria, International Electronic Engineering Mathematical Society IEEMS, Volume (7), pp. 109-126.

Swingler, K. (1996). Applying Neural Networks: A Practical Guide, Academic Press, London UK, pp. 21-39. 